(C) The Author(s), 2021. Published by Cambridge University Press on behalf of University of Notre Dame doi:10.1017/S0034670521000644

\title{
Aristocratic Insolenzia and the Role of Senates in Machiavelli's Mixed Republic- CORRIGENDUM
}

\author{
John P. McCormick
}

https://doi.org/10.1017/S0034670521000486. Published by Cambridge University Press, 24 August 2021

In footnotes 10 and 11 of the original online version of the article by McCormick, ${ }^{1}$ an article by Arum $^{2}$ was cited with the wrong title. The correct title should be as listed per the footnotes, as follows:

${ }^{10}$ See Livy 2.21. Machiavelli's consistent affiliation of insolence with avarice, cruelty, and ambition suggests an affinity with Aristotle's notion of pleonexia. See Gordon Arlen, "Aristotle and the Problem of Oligarchic Harm: Insights for Democracy," European Journal of Political Theory 18, no. 3 (July 2019): 393-414. Zuckert, on the contrary, argues that it is incorrect to attribute a "moralistic" condemnation of vices, such as avarice, to Machiavelli: see Zuckert, "Machiavelli: Radical Democratic Political Theorist?," 502. Even if this were correct, Machiavelli certainly levels rather frequent political condemnations of such vices. See Eero Arum, "Machiavelli's Principio: Political Renewal and Innovation in the Discourses on Livy." Review of Politics 82, no. 4 (2020): 525-47.

${ }^{11}$ Of the transgressors named in D 3.1-the sons of Brutus, the decemvirs, Spurius Maelius, and Manlius Capitolinus-only Maelius is not a noble, although he is an exceedingly wealthy plebeian. On D 3.1 more generally, see Arum, "Machiavelli's Principio."

The article title has been corrected in the footnotes.

\footnotetext{
${ }^{1}$ John P. McCormick, “Aristocratic Insolenzia and the Role of Senates in Machiavelli's Mixed Republic," Review of Politics 83, no. 4 (2021): 486-509. https://doi.org/10.1017/ S0034670521000486.

${ }^{2}$ Eero Arum, "Machiavelli's Principio: Political Renewal and Innovation in the Discourses on Livy." Review of Politics 82, no. 4 (2020): 525-47.
} 